\title{
Helicobacter pylori is not associated with anaemia in Latin America: results from Argentina, Brazil, Bolivia, Cuba, Mexico and Venezuela
}

Ina S Santos ${ }^{1, *}$, Jose Boccio ${ }^{2}$, Lena Davidsson ${ }^{3}$, Manuel Hernandez-Triana ${ }^{4}$, Elizabeth Huanca-Sardinas ${ }^{5}$, Mariana Janjetic ${ }^{2}$, Silvia Y Moya-Camarena ${ }^{6}$, Maria C Paez-Valery', Vladimir Ruiz-Alvarez ${ }^{4}$, Mauro E Valencia ${ }^{6}$, Neiva CJ Valle ${ }^{1}$, Greta Vargas-Pinto ${ }^{5}$, Liseti Solano ${ }^{7}$ and Julian Thomas ${ }^{8}$

${ }^{1}$ Postgraduate Course Epidemiology, Federal University of Pelotas, Rua Marechal Deodoro 1160 , Pelotas, RS, Brazil: ${ }^{2}$ Stable Isotopes Laboratory, School of Pharmacy and Biochemistry, University of Buenos Aires, Buenos Aires, Argentina: ${ }^{3}$ International Atomic Energy Agency, Nutritional and Health-Related Environmental Studies Section, Vienna, Austria: ${ }^{4}$ Department of Biochemistry and Physiology, Institute of Nutrition and Food Hygiene, Havana, Cuba: ${ }^{5}$ Institute of Nuclear Medicine, San Francisco Xavier de Chuquisaca University, Sucre, Bolivia: ${ }^{6}$ Research Centre for Food Development, Department of Nutrition and Metabolism, Hermosillo, Mexico: ${ }^{7}$ Centre of Nutritional Research, Carabobo University, Barbula, Valencia, Venezuela: ${ }^{8}$ School of Clinical Medical Sciences (Child Health), Newcastle University, Newcastle upon Tyne, UK

Submitted 20 February 2008: Accepted 7 December 2008: First published online 4 March 2009

\begin{abstract}
Objective: To investigate the association between Helicobacter pylori infection and anaemia.

Design: Six cross-sectional studies. H. pylori infection was assessed by the $\left[{ }^{13} \mathrm{C}\right]$ urea breath test using MS or IR analysis. Hb was measured for all countries. Ferritin and transferrin receptors were measured for Argentina, Bolivia, Mexico, and Venezuela.

Setting: Health services in Argentina, Brazil and Mexico or public schools in Bolivia, Cuba and Venezuela.

Subjects: In Argentina, 307 children aged 4-17 years referred to a gastroenterology unit; in Bolivia, 424 randomly selected schoolchildren aged 5-8 years; in Brazil, 1007 adults (157 men, 850 women) aged 18-45 years attending thirty-one primary healthcare units; in Cuba, 996 randomly selected schoolchildren aged 6-14 years; in Mexico, seventy-one pregnant women in their first trimester attending public health clinics; in Venezuela, 418 children aged 4-13 years attending public schools.

Results: The lowest prevalence of H. pylori found was among children in Argentina (25.1\%) and the highest in Bolivia (74.0\%). In Bolivia, Cuba and Venezuela children showed similar prevalence of $H$. pylori infection as in Brazilian and Mexican adults (range $47.5 \%$ to $81 \cdot 8 \%$ ). Overall anaemia prevalence was 11.3\% in Argentina, $15 \cdot 4 \%$ in Bolivia, 20.6\% in Brazil, 10.5\% in Cuba and $8.9 \%$ in Venezuela. Adjusted analyses allowing for confounding variables showed no association between $H$. pylori colonization and anaemia in any study. $\mathrm{Hb}$, ferritin and transferrin receptor levels were also not associated with $H$. pylori infection in any country.

Conclusions: The present study showed no evidence to support the hypothesis that $H$. pylori contributes to anaemia in children, adolescents, adults or pregnant women in six Latin American countries.
\end{abstract}

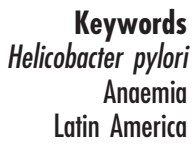

Eradication of Helicobacter pylori infection has been recommended for patients with unexplained Fe-deficiency anaemia $^{(1,2)}$. This recommendation is based on case reports, cross-sectional studies and limited data from intervention studies $^{(3-37)}$. Fe deficiency is the most common nutritional deficiency in Latin American countries ${ }^{(38)}$. It is important to establish whether H. pylori, which is common throughout the region ${ }^{(39-44)}$, could account for the increased prevalence of anaemia, particularly among vulnerable groups including children and pregnant women.

In 2002 The International Atomic Energy Agency started an international multi-centre regional project (ARCAL-RLA 
6042-6054). During phase I of the project, the main outcomes were standardization of the $\left[{ }^{13} \mathrm{C}\right]$ urea breath test $\left({ }^{13} \mathrm{C}\right.$-UBT $)$ for the diagnosis of $H$. pylori and assessment of the association between $H$. pylori and socio-economic, environmental and demographic factors. In phase II, the main outcome was assessment of possible associations between $H$. pylori and anaemia. The results obtained from six Latin American countries - Argentina, Bolivia, Brazil, Cuba, Mexico and Venezuela - are presented in the current article.

\section{Experimental methods}

The present coordinated series of cross-sectional studies aimed to investigate the relationship between $H$. pylori and anaemia in Latin America. Coordinating meetings were held before defining protocols and primary outcome measures. Each centre produced specific protocols including secondary outcomes relevant to their own communities, and identified local populations at risk of Fe deficiency in whom H. pylori might be a contributing factor. Argentina, Bolivia, Cuba and Venezuela studied children, Brazil studied adults and Mexico included pregnant women. Full details of these study groups are given below. For sample size calculation, $\alpha$ and $\beta$ errors were set at 0.05 and $0 \cdot 20$, respectively, and relative risk at $\geq 2 \cdot 0$ for all countries. A value of $15 \%$ was added to account for expected refusals and subject drop-out, and $30 \%$ to allow adequate controlling of confounding factors. The estimated local prevalences of $H$. pylori and anaemia were used to calculate the minimum sample size in each population.

\section{Subjects}

\section{Argentina}

A sample size of 150 was calculated estimating a ratio of H. pylori-positive to $H$. pylori-negative of 2:3 and prevalence of anaemia of $30 \%$ among unexposed ( $H$. pylori-negative) children. A total of 307 children aged 4 to 17 years, referred to the Gastroenterology Unit of the 'Superiora Sor Maria Ludovica' Children's Hospital for evaluation of upper gastrointestinal symptoms (gastro-oesophageal reflux, symptoms of oesophagitis, dyspepsia and abdominal pain), were enrolled. The hospital is a tertiary-level health-care referral institution treating children with complex clinical problems from the Province of Buenos Aires. Forty per cent of the country's population live in this province. The Gastroenterology Unit receives on average 600 patients per month. Subjects taking antibiotics or acid suppressants during the previous month or mineral supplements (including $\mathrm{Fe}$ ) during the previous three months were excluded. Data collection was carried out from April 2006 to May 2007.

\section{Bolivia}

A sample size of 400 was calculated estimating a ratio of H. pylori-positive to H. pylori-negative of 1:1 and prevalence of anaemia of $15 \%$ among unexposed children. From a population of 24121 children aged 5-8 years attending public schools in the city of Sucre, 424 children were randomly selected from four large schools (also selected at random), proportional to the number of students attending each school. Any children who were clinically unwell at recruitment were excluded. Field work took place from May 2006 to April 2007.

\section{Brazil}

A sample size of 909 was calculated estimating a ratio of H. pylori-positive to $H$. pylori-negative of 3:1 and anaemia prevalence among $H$. pylori-negative subjects of $10 \%$. The study was carried out in all thirty-one primary healthcare units (PHU) within the National Health System, in the urban zone of Pelotas, between August 2006 and February 2007. Data collection in each PHU lasted approximately one week. The study included all adults aged 18 to 45 years who were users of the PHU and were in the waiting room for any reason on study days. The maximum age was defined as 45 years in order to avoid cases of anaemia due to malignancy. Only adults unable to complete the interview were excluded.

\section{Cuba}

A minimum sample size of 500 was calculated estimating a ratio of $H$. pylori-positive to $H$. pylori-negative of $2: 3$ and anaemia prevalence among $H$. pylori-negative subjects of $35 \%$. All urban and rural public schools in the community of Yaguajay were eligible for inclusion in the study and thirty-nine schools were randomly selected. A random sample of 996 children aged 6-14 years was then selected from these schools. Clinical records of school physicians were reviewed and only healthy children were eligible for inclusion. Children who had taken antibiotics, acid suppressants or Fe supplements during the previous month were excluded. Data collection was carried out in June 2006.

\section{Mexico}

A sample size of 182 was calculated estimating a ratio of H. pylori-positive to $H$. pylori-negative of $1: 1$ and frequency of anaemia of $20 \%$. Women were recruited from public health sector clinics after their first contact visit for prenatal care and referred directly to the responsible researcher. All women enrolled in the study were in their first trimester of pregnancy. Volunteers who had taken vitamin or mineral supplements in the first trimester, antacids or antibiotics one month prior to the study were excluded. Data collection started in November 2006. To date, a total of seventy-one pregnant women aged 14-32 years have been enrolled in the study.

\section{Venezuela}

A sample size of 312 was calculated estimating a ratio of $H$. pylori-positive to $H$. pylori-negative of $3: 1$ and anaemia prevalence among $H$. pylori-negative subjects of $17 \%$. 
A total of 478 children aged 4-14 years from public schools in the community of Celio Celli were enrolled. The study zone is in the Municipality of Valencia and comprises eleven educational units with a total of 5691 students. The selection of the schools was made by intentional sampling allowing for schools with the highest number of students, acceptance of the study from parents and members of the educational community, and security conditions. Children taking antibiotics or acid suppressants during the two months before data collection were excluded. Data collection was carried out from May to September 2006.

\section{Determination of $\mathrm{H}$. pylori infection}

The ${ }^{13} \mathrm{C}$-UBT was used for detecting $H$. pylori as previously described $^{(45)}$. Briefly, participants were instructed to fast for at least $6 \mathrm{~h}$, after which two samples of exhaled air were collected by trained field workers to determine basal ${ }^{13} \mathrm{C}:{ }^{12} \mathrm{C}$ ratio. Then, $50 \mathrm{mg}$ of $\left[{ }^{13} \mathrm{C}\right]$ urea (Cambridge Isotope Laboratories Inc., Andover, MA, USA) were ingested by each patient with an appropriate test meal. Bolivia and Cuba used IR spectroscopy to analyse breath samples, while all other countries used isotope ratio mass spectrometry (IRMS). For IRMS, samples were collected at 30 and $45 \mathrm{~min}$ after ingestion of the labelled solution, stored in hermetically sealed containers (Labco Limited, High Wycombe, UK) and isotope ratios measured using a mass spectrometer coupled to a gas chromatograph (Finnigan MAT GmbH and ThermoQuest Corp., Bremen, Germany). For IR spectroscopy, exhaled breath was collected $30 \mathrm{~min}$ after ingestion of labelled solution in gas-tight sample bags and analysed (FANci 2 or IRIS 2; Fischer Analysen Instrumente GmbH, Leipzig, Germany; Van Loenen Instruments, Zaandam, The Netherlands) on the day of collection.

A change of $>3.5 \%$ in the delta over baseline values was considered positive ${ }^{(45)}$.

\section{Anaemia definition}

Argentina, Bolivia, Mexico and Venezuela measured $\mathrm{Hb}$ from venepuncture samples; in Brazil and Cuba, fingerpick samples were analysed using a portable haemoglobin meter (HemoCue ${ }^{\circledR}$; HemoCue Inc., Lake Forest, CA, USA). Blood samples were obtained by trained field workers. Anaemia was diagnosed according to $\mathrm{WHO}$ criteria $^{(46)}$ at the following $\mathrm{Hb}$ levels: children below 12 years, $\mathrm{Hb}<11.5 \mathrm{~g} / \mathrm{dl}$ or $<12.7 \mathrm{~g} / \mathrm{dl}$ for Bolivia in order to account for altitude ( $2750 \mathrm{~m})$; pregnant women, $\mathrm{Hb}<11 \mathrm{~g} / \mathrm{dl}$; non-pregnant women, $\mathrm{Hb}<12 \mathrm{~g} / \mathrm{dl}$; and men, $\mathrm{Hb}<13 \mathrm{~g} / \mathrm{dl}$.

\section{Fe status measure}

Serum ferritin levels were measured in Argentina and Venezuela by RIA (Diagnostic Systems Laboratories, Webster, TX, USA) and transferrin receptors by enzyme immunoassay (TF-94; Ramco Laboratories, Stafford, TX, USA). In Bolivia and Mexico, ferritin was measured by the Coat-A-Count Ferritin IRMA (Diagnostics Products
Corporation, Los Angeles, CA, USA) and serum transferrin receptors by ELISA ( $\mathrm{R} \& \mathrm{D}$ Systems Inc., Minneapolis, MN, USA). Samples were analysed in duplicate. Quality control was performed running three controls with known concentration of transferrin receptors in the assay (supplied in the kit). The values obtained were within the established ranges supplied with the kit. C-reactive protein (CRP) level was measured with the Protex-CR kit (Lafon Labs, Mexico).

Cut-off points for ferritin level were defined as $<2 \mu \mathrm{g} / 1$ for children $<5$ years of age and as $<15 \mu \mathrm{g} / 1$ for $\geq 5$-yearolds. For pregnant women ferritin cut-off was also $<12 \mu \mathrm{g} / 1$. The cut-off point for transferrin receptor level was defined as $>28 \mathrm{nmol} / 1$ for all groups.

\section{Confounding variables}

A structured questionnaire was used to collect information on potential confounding factors. Pilot studies with these questionnaires were undertaken in each country before data collection began, to train field workers and develop study logistics.

\section{Demographic variables}

Age and sex of subjects were collected for all countries. In Brazil, skin colour as observed by the interviewer was recorded as this has previously been shown to be a marker of socio-economic status in this population ${ }^{(47,48)}$.

\section{Socio-economic characteristics}

Argentina, Brazil, Cuba, Mexico and Venezuela collected data on family income, level of education of the subjects (parents in the case of children), housing conditions (type of house, source of water, sanitation and crowding) and rural/urban residency.

\section{Dietary Fe intake}

Argentina and Cuba conducted a $24 \mathrm{~h}$ dietary recall for the whole group or a sub-sample, respectively, from parents. Fe intakes were estimated for foods using a nutrient composition database (INFOODS) compiled by ARGENFOODS $^{(49)}$ from the FAO ${ }^{(50)}$ and US Department of Agriculture food database ${ }^{(51)}$. For Brazil, weekly frequency of consumption of Fe-rich foods was assessed.

\section{Anthropometric data}

Height and weight were recorded by trained field workers using anthropometers and calibrated scales. For adults, $\mathrm{BMI} \leq 18.5 \mathrm{~kg} / \mathrm{m}^{2}$ was classified as underweight; $\mathrm{BMI}=18 \cdot 6-24 \cdot 9 \mathrm{~kg} / \mathrm{m}^{2}$ as normal weight; $\mathrm{BMI}=$ $25 \cdot 0-29 \cdot 9 \mathrm{~kg} / \mathrm{m}^{2}$ as overweight; and $\mathrm{BMI} \geq 30 \cdot 0 \mathrm{~kg} / \mathrm{m}^{2}$ as obese. In Argentina and Cuba, children's height and weight were expressed as Z-scores relative to the 2000 Centers for Disease Control and Prevention age- and sex-appropriate standards ${ }^{(52)}$. Underweight and stunted were classified as $>2$ sD below median values for weightfor-age and height-for-age, respectively. 


\section{General health}

In Brazil adults were asked about smoking and consumption of alcoholic beverages, previously diagnosed anaemia, and the presence of haemorrhoids or blood in faeces. For women, additional questions addressed reproductive and menstrual history.

\section{Parasites}

Cuba used microscopy of fresh faeces by the Kato-Katz method to identify intestinal parasites, specifically Necator americanus, Ascaris lumbricoides and Trichiuris trichiuria. All analyses were carried out by two microbiologists under the supervision of the principal investigator.

\section{Quality control}

Quality control of data collection was achieved through close supervision of the interviewers, review of the questionnaires and weekly meetings of the field workers with the research assistants at each study site. Quality control for ${ }^{13} \mathrm{CO}_{2}$ was based on having two identical IRMS units in each laboratory (Finnigan MAT GmbH and ThermoQuest Corp.) and identical protocols ${ }^{(45)}$ in Argentina and Mexico. Analysis of the same samples on various occasions, with different combinations of subjects with values above or below $3.5 \%$ in the delta over baseline values, always classified positivity or negativity equally.

\section{Statistical analyses}

Prevalence of anaemia was compared between $H$. pyloripositive and -negative subjects using the $\chi^{2}$ test. Crude and adjusted analyses were made through logistic regression (for anaemia) and linear regression (for $\mathrm{Hb}$, ferritin and transferrin receptor levels) taking into account the natural clustering of the data as might occur according to PHU in Brazil and schools in Bolivia and Cuba. In all analyses, variables were considered to be possible confounders of the effect of $H$. pylori on the outcome if they were associated with both outcome and $H$. pylori with $P<0 \cdot 20$. Crude and adjusted odds ratios and $\beta$ coefficients were obtained with $95 \%$ confidence intervals. Data from Mexico were used uniquely in linear regression analyses because only two of the seventy-one enrolled women presented anaemia. Analyses were performed using the STATA statistical software package version $9 \cdot 0$ (StataCorp., College Station, TX, USA).

All studies were approved by the relevant institutions' Research Ethics Committee and Institutional Research Boards. All subjects or parents gave written informed consent for participation. All results on H. pylori and blood parameters were sent to the responsible health facilities in Argentina, Brazil and Mexico so that the appropriate treatment could be given. In Bolivia and Venezuela results were given directly to families along with a referral letter to a paediatrician in the case of abnormal results. In Cuba children with anaemia were treated with Fe salts after the diagnosis.

\section{Results}

The overall non-response rate for the study was $10 \cdot 4 \%$, $0 \%, 8 \cdot 1 \%, 1.5 \%, 0 \%$ and $11.6 \%$, respectively, in Argentina, Bolivia, Brazil, Cuba, Mexico and Venezuela.

\section{Prevalence of $\mathrm{H}$. pylori infection}

Incomplete data rates for ${ }^{13} \mathrm{C}$-UBT were $0 \%, 13 \cdot 0 \%$, $2.9 \%, 0.5 \%$ and $12 \cdot 1 \%$, respectively, in Argentina, Bolivia, Brazil, Cuba and Venezuela. Table 1 compares the prevalence of $H$. pylori with anaemia in each country. The lowest prevalence of $H$. pylori found was among children in Argentina (25.1\%), followed by Cuba (47.7\%). Schoolchildren in Bolivia and Venezuela showed similar prevalence of $H$. pylori as Brazilian and Mexican adults, ranging from $47 \cdot 5 \%$ to $81 \cdot 8 \%$.

\section{Prevalence of anaemia}

Incomplete data rates for $\mathrm{Hb}$ measures were $16 \cdot 3 \%, 0 \%$, $2 \cdot 3 \%, 0.5 \%, 0 \%$ and $2 \cdot 0 \%$, respectively, in Argentina, Bolivia, Brazil, Cuba, Mexico and Venezuela. Overall anaemia prevalence $(95 \% \mathrm{CI})$ was $11 \cdot 3 \%(7 \cdot 4,15 \cdot 2 \%)$ in Argentina, $15 \cdot 4 \%(11 \cdot 9,18 \cdot 8 \%)$ in Bolivia, 20.6\% (18.2, $23 \cdot 2 \%)$ in Brazil, $10 \cdot 5 \%(8 \cdot 6,12 \cdot 5 \%)$ in Cuba and $8 \cdot 9 \%$ $(6 \cdot 1,11 \cdot 6 \%)$ in Venezuela. Except for Mexico, the prevalence of anaemia in $H$. pylori-positive or -negative subjects was compared. There were no differences between colonized and non-colonized subjects in any country except for Venezuela, where a significant difference was observed with anaemia more prevalent in $H$. pylori-negative $(15 \cdot 1 \%)$ than in $H$. pylori-positive $(7 \cdot 1 \%)$ subjects.

\section{Estimated risk of anaemia}

For all countries except Venezuela, 95\% confidence intervals of crude odds ratios of anaemia associated with H. pylori included unity. In Venezuela, the crude odds ratio suggested $H$. pylori-colonized children had a decreased risk of anaemia. Adjusted analyses allowing for confounding variables identified as described above showed no change in risk of anaemia associated with H. pylori in any study (Table 1 ).

$\mathrm{Hb}$ was also analysed as a continuous variable with respect to $H$. pylori (Table 2 ). The crude $\beta$ coefficients suggested that $H$. pylori-colonized children from Venezuela had elevated $\mathrm{Hb}$ levels, but no significant effect was observed in other countries. After adjusting for confounding variables, no significant effects were detected in any population.

\section{Fe status}

Low ferritin concentration was observed in $8 \cdot 8 \%, 2 \cdot 8 \%$ and $4.6 \%$, respectively, of the children in Argentina, Bolivia and Venezuela; and in $12.7 \%$ of the pregnant women in Mexico. The prevalence of high transferrin receptor level was $31 \cdot 5 \%$ and $57 \cdot 2 \%$, respectively, in 
Bolivia and in Venezuela. In Argentina and Mexico, none of the studied subjects presented high transferrin receptor levels.

Table 3 summarizes the effect of $H$. pylori on serum ferritin and transferrin receptors. There was a negative trend of association in ferritin levels that did not achieve significance in Argentina and Mexico, and a positive crude association between H. pylori and transferrin receptor levels in Mexican pregnant women.

\section{Discussion}

Anaemia and H. pylori are both common throughout Latin America. The present coordinated series of studies, involving different geographical regions and including subjects from childhood to adulthood, detected no association between these two conditions.

A potential link between $H$. pylori and Fe-deficiency anaemia was first proposed in $1990^{(4)}$ and supported by a series of case reports ${ }^{(5-15)}$. Additional evidence was provided by five well-designed cross-sectional studies ${ }^{(16-20)}$, although two further studies failed to detect an association $^{(53,54)}$. Four cross-sectional studies suggested that other indicators of low Fe status were associated with H. pylori ${ }^{(21-24)}$, and five publications involving selected groups of subjects also supported a link between H. pylori and Fe-deficiency anaemia ${ }^{(25-29)}$. Conflicting results have been obtained from some communities. A recent description of work undertaken several years ago in Alaska found that $H$. pylori IgG seropositivity was associated with Fe-deficiency anaemia, whereas in the same subjects, $H$. pylori detected by ${ }^{13} \mathrm{C}$-UBT or faecal antigen test was not ${ }^{(55)}$. This contrasts with the findings of another large population study among Alaskan Natives ${ }^{(20)}$, and encourages a cautious approach to interpreting the results of these data.

Several authors have suggested that $H$. pylori may cause Fe deficiency. In situations such as that described in Alaskan Natives, where a haemorrhagic gastritis was described in $H$. pylori-infected adults ${ }^{(16)}$, a clear aetiology could be proposed. Others have suggested that a defect in $\mathrm{Fe}$ absorption may occur ${ }^{(27)}$. Plausible mechanisms could involve decrease of mucosal Fe absorption capacity due to reduced gastric acid output ${ }^{(56)}$, competition of the bacterium with the host for the dietary Fe supply ${ }^{(33)}$, reduction of the gastric juice vitamin $\mathrm{C}$ content in infected subjects $^{(57)}$, increased hepcidin production from hepatocytes in response to IL-6 production associated with H. pylori gastritis ${ }^{(58)}$ or sequestration of $\mathrm{Fe}$ in lactoferrin in the gastric mucosa ${ }^{(59)}$. However, a detailed study of $\mathrm{Fe}$ absorption using stable isotopes from Bangladesh did not show a difference in Fe absorption between $H$. pyloricolonized anaemic children and anaemic controls, and also failed to show any improvement in Fe absorption after $H$. pylori eradication ${ }^{(60)}$. 
Table 2 Crude and adjusted $\beta$ coefficients for $\mathrm{Hb}$ level according to Helicobacter pylori in six countries in Latin America

\begin{tabular}{lcccrr}
\hline Country & $\beta$ coefficient crude & $95 \% \mathrm{Cl}$ & $P$ & $\beta$ coefficient adjusted & $95 \% \mathrm{Cl}$ \\
\hline Argentina & 0.11 & $-0.42,0.21$ & 0.5 & $0.02^{*}$ & $-0.31,0.35$ \\
Bolivia & 0.79 & $-5.24,6.81$ & 0.7 & $0.36 \dagger$ & $-5.86,6.58$ \\
Brazil & -0.17 & $-0.38,-0.05$ & 0.1 & $-0.07 \ddagger$ & 0.9 \\
Cuba & -0.62 & $-2.34,1 \cdot 10$ & 0.5 & $-1.17 \S$ & $-0.24,0.11$ \\
Mexico & -0.02 & $-0.54,0.49$ & 0.9 & $-0.02 \|$ & $-3.09,0.75$ \\
Venezuela & 0.31 & $0.10,0.52$ & 0.004 & -0.32 & $-0.54,0.49$ \\
\hline
\end{tabular}

${ }^{*}$ Adjusted for maternal education and crowding.

tAdjusted for age.

¥Adjusted for sex, skin colour, income, age and smoking.

$\S$ Adjusted for age, father's education and sanitation.

IIThere was no confounding by age.

-Adjusted for age.

H. pylori is genetically diverse and type I strains, which are $\mathrm{CagA}^{+}$and secrete the vacuolating cytotoxin, are assumed to be the most virulent ${ }^{(61,62)}$, being associated with the presence of more severe disease ${ }^{(63-69)}$. Increased bacterial load could also promote gastric inflammation ${ }^{(70)}$ which therefore could stimulate epithelial damage and increase disease severity. Most studies that have reported an association of $H$. pylori with Fe status have not been able to investigate the potential role of bacterial load or genotype.

Despite the supportive evidence summarized above, relatively few intervention studies have sought to establish whether H. pylori contributes directly to the development of Fe deficiency and anaemia. Six open studies have observed improvements in anaemia and $\mathrm{Fe}$ status associated with $H$. pylori eradication ${ }^{(30-35)}$. A randomized controlled trial did suggest a role for H. pylori in causing anaemia among adolescents, but only included small numbers of subjects ${ }^{(36)}$. A larger randomized study evaluating response of anaemia to different forms of $\mathrm{Fe}$ supplementation found that the presence of $H$. pylori had a negative effect on treatment success ${ }^{(37)}$, but an even larger open label study failed to demonstrate any improvement in Fe-deficiency anaemia attributable to H. pylori eradication ${ }^{(71)}$.

The available data thus suggest that $H$. pylori plays a role in the development of Fe-deficiency anaemia in certain individuals and selected populations, but falls short of providing firm evidence to support the conclusion drawn by several authors of the studies described above, that $H$. pylori causes Fe deficiency and is thus a significant public health concern.

Our studies demonstrate that H. pylori is common from early childhood in Latin America, particularly in communities such as that studied in Bolivia, where $74 \%$ of children were colonized. No significant associations between $H$. pylori and anaemia were detected in any study after allowing for confounding variables. In children from Venezuela, those colonized by H. pylori tended to have higher levels of $\mathrm{Hb}$ than controls. Analyses of ferritin and transferrin receptor levels also failed to produce conclusive or consistent results between different populations.
A source of criticism to our results is that not all countries have measured Fe status and that concomitant infectious diseases may have falsely increased the ferritin levels. This was only accounted for in Mexico and Venezuela. All subjects, however, were CRP-negative in Mexico and only a small number were positive in Venezuela, reinforcing serum ferritin as a valid indicator of $\mathrm{Fe}$ status in community studies of healthy individuals ${ }^{(46)}$

A potential source of bias in cross-sectional studies is inverse causality in which the exposure of interest is in fact the consequence not the cause of the studied outcome. This is not the case in the current studies, in which no association was found. The main feature to emerge from this combined data set is the lack of any single clear message concerning the relationship between $H$. pylori and anaemia. Sporadic associations (both positive and negative) were detected in individual populations, making it likely that if we extended our work, we would inevitably encounter a population in which H. pylori appeared to be associated with anaemia. This raises the possibility that the preponderance of cross-sectional studies describing an association between Fe deficiency and H. pylori over those failing to detect such an association may have been influenced by 'positive finding' publication bias.

Our coordinated approach, which is the principal strength of the current report, has produced no evidence to support the hypothesis that $H$. pylori contributes to anaemia in children, adolescents or adults throughout our region. We highlight the importance of presenting potentially exciting results, such as the trends of association between $H$. pylori and ferritin levels in Argentina and Mexico, in the context of less exciting (and by extension potentially less publishable) results from similar studies. In order to infer causality from associations uncovered in epidemiological reports, a key requirement is for consistency of results between different studies. The lack of association between $H$. pylori and anaemia in the present series of cross-sectional studies argues against this common gastric pathogen being a significant cause of anaemia in Latin America. 


\section{Acknowledgements}

Sources of funding: The studies were supported by funds from the International Atomic Energy Agency (IAEA) (projects ARCAL RLA 6042 and RLA 6054) and from the countries' ministries of health. Conflict of interest: There is no conflict of interest. Authors' contributions: I.S.S., J.B., M.H.-T., M.C.P.-V., M.E.V. and G.V.-P. are the principal investigators of the studies in their respective countries. The statistical analyses and the first version of the manuscript were completed in a coordinated meeting attended by the principal investigators together with J.T. in Pelotas, Brazil. L.D. criticized and made inputs to the first version of the manuscript. N.C.J.V. helped to carry out the statistical analysis for all countries. E.H.-S., M.J., S.Y.M.-C., V.R.-A. and L.S. contributed in the field work conduction and by running the laboratory analyses in their respective countries. All authors reviewed and approved the last version of the manuscript. Acknowledgements: The authors are grateful to all participants, the IAEA and the corresponding national energy commissions, and the health authorities of each participating country.

\section{References}

1. Malfertheiner P, Megraud F, O'Morain C, Bazzoli F, El-Omar E, Graham D, Hunt R, Rokkas T, Vakil N \& Kuipers EJ (2007) Current concepts in the management of Helicobacter pylori: the Maastricht III Consensus Report. Gut 56, 772-781.

2. Caselli M, Zullo A, Maconi G, Parente F, Alvisi V, Casetti T, Sorrentino D \& Gasbarrini G; Working Group of the Cervia II Meeting (2007) 'Cervia II Working Group Report 2006': guidelines on diagnosis and treatment of Helicobacter pylori in Italy. Dig Liver Dis 39, 782-789.

3. Kearney D (2005) Helicobacter pylori and iron deficiency anemia: accumulating evidence in support of a real association. Indian J Gastroenterol 24, 147-150.

4. Zhu F \& Riddell RH (1990) Iron deficiency in Helicobacter (Campylobacter) pylori. J Clin Gastroenterol 12, 244.

5. Bruel LH, Dabadie A, Pouedras P, Gambert C, Legall E \& Jezequel C (1993) Acute anemia as the 1st manifestation of Helicobacter pylori gastritis. Ann Pediatr $\mathbf{4 0}$, 364-367.

6. Marignani M, Angeletti S, Bordi C, Malagnino F, Mancino C, Delle Fave G \& Annibale B (1997) Reversal of longstanding iron deficiency anaemia after eradication of Helicobacter pylori. Scand J Gastroenterol 32, 617-622.

7. Banin P, Biserna L, Navarra M, Urso L, Mandrioli G \& De Sanctis V (1998) Helicobacter pylori and iron deficiency: report of two cases in the same family. Ital J Pediatr $\mathbf{2 4}$, 1021-1024.

8. Choe YH, Lee JE \& Kim SK (2000) Effect of Helicobacter pylori eradication on sideropenic refractory anaemia in adolescent girls with Helicobacter pylori. Acta Paediatr 89, 154-157.

9. Konno M, Muraoka S, Takahashi M \& Imai T (2000) Irondeficiency anemia associated with Helicobacter pylori gastritis. J Pediatr Gastroenterol Nutr 31, 52-56.

10. Ashorn M, Ruuska T \& Makipernaa A (2001) Helicobacter pylori and iron deficiency anaemia in children. Scand $J$ Gastroenterol 36, 701-705. 
11. Sugiyama T, Tsuchida M, Yokota K, Shimodan M \& Asaka M (2002) Improvement of long-standing iron-deficiency anemia in adults after eradication of Helicobacter pylori. Intern Med 41, 491-494.

12. Kostaki M, Fessatou S \& Karpathios T (2003) Refractory iron-deficiency anaemia due to silent Helicobacter pylori gastritis in children. Eur J Pediatr 162, 177-179.

13. Yoshimura M, Hirai M, Tanaka N, Kasahara Y \& Hosokawa O (2003) Remission of severe anemia persisting for over 20 years after eradication of Helicobacter pylori in cases of Menetrier's disease and atrophic gastritis: Helicobacter pylori as a pathogenic factor in iron-deficiency anemia. Intern Med 42, 971-977.

14. Russo-Mancuso G, Branciforte F, Licciardello M \& La Spina M (2003) Iron deficiency anemia as the only sign of infection with Helicobacter pylori: a report of 9 pediatric cases. Int J Hematol 78, 429-431.

15. Diop S, Aouba A \& Varet B (2004) Reversal of iron deficiency anaemia after eradication of Helicobacter pylori. Presse Med 33, 1517-1518.

16. Yip R, Limburg PJ, Ahlquist DA et al. (1997) Pervasive occult gastrointestinal bleeding in an Alaska native population with prevalent iron deficiency - role of Helicobacter pylori gastritis. JAMA 277, 1135-1139.

17. Seo JK, Ko JS \& Choi KD (2002) Serum ferritin and Helicobacter pylori in children: a sero-epidemiologic study in Korea. J Gastroenterol Hepatol 17, 754-757.

18. Weyermann M, Rothenbacher D, Gayer L, Bode G, Adler G, Grab D, Flock F \& Brenner H (2005) Role of Helicobacter pylori in iron deficiency during pregnancy. Am J Obst Gynecol 192, 548-553.

19. Cardenas VM, Mulla ZD, Ortiz M \& Graham DY (2006) Iron deficiency and Helicobacter pylori in the United States. Am J Epidemiol 163, 127-134.

20. Baggett HC, Parkinson AJ, Muth PT, Gold BD \& Gessner BD (2006) Endemic iron deficiency associated with Helicobacter pylori among school-aged children in Alaska. Pediatrics 117, E396-E404.

21. Peach HG, Bath NE \& Farish SJ (1998) Helicobacter pylori: an added stressor on iron status of women in the community. Med J Aust 169, 188-190.

22. Collett JA, Burt MJ, Frampton CMA, Yeo KH, Chapman TM, Buttimore RC, Cook HB \& Chapman BA (1999) Seroprevalence of Helicobacter pylori in the adult population of Christchurch: risk factors and relationship to dyspeptic symptoms and iron studies. N Z Med J 112, 292-295.

23. Parkinson AJ, Gold BD, Bulkow L, Wainwright RB, Swaminathan B, Khanna B, Petersen KM \& Fitzgerald MA (2000) High prevalence of Helicobacter pylori in the Alaska native population and association with low serum ferritin levels in young adults. Clin Diag Lab Immunol 7, 885-888.

24. Berg G, Bode G, Blettner M, Boeing H \& Brenner H (2001) Helicobacter pylori and serum ferritin: a population-based study among 1806 adults in Germany. Am J Gastroenterol 96, 1014-1018.

25. Choe YH, Kwon YS, Jung MK, Kang SK, Hwang TS \& Hong YC (2001) Helicobacter pylori-associated iron-deficiency anemia in adolescent female athletes. J Pediatr 139, 100-104.

26. Nahon S, Lahmek P, Massard J, Lesgourgues B, Mariaud de Serre N, Traissac L, Bodiguel V, Adotti F \& Delas N (2003) Helicobacter pylori-associated chronic gastritis and unexplained iron deficiency anemia: a reliable association? Helicobacter 8, 573-577.

27. Baysoy G, Ertem D, Ademoglu E, Kotiloglu E, Keskin S \& Pehlivanoglu E (2004) Gastric histopathology, iron status and iron deficiency anemia in children with Helicobacter pylori. J Pediatr Gastroenterol Nutr 38, 146-151.

28. Yang YJ, Sheu BS, Lee SC, Yang HB \& Wu JJ (2005) Children of Helicobacter pylori-infected dyspeptic mothers are predisposed to $H$. pylori acquisition with subsequent iron deficiency and growth retardation. Helicobacter 10, 249-255.

29. Akcam M, Ozdem S, Yilmaz A, Gultekin M \& Artan R (2007) Serum ferritin, vitamin B-12, folate, and zinc levels in children infected with Helicobacter pylori. Dig Dis Sci 52, 405-410.

30. Hershko C, Ianculovich M \& Souroujon M (2007) A hematologist's view of unexplained iron deficiency anemia in males: impact of Helicobacter pylori eradication. Blood Cells Mol Dis 38, 45-53.

31. Hershko C, Hoffbrand AV, Keret D, Souroujon M, Maschler I, Monselise Y \& Lahad A (2005) Role of autoimmune gastritis, Helicobacter pylori and celiac disease in refractory or unexplained iron deficiency anemia. Haematol J 90, $585-595$.

32. Kurekci AE, Atay AA, Sarici SU, Yesilkaya E, Senses Z, Okutan V \& Ozcan O (2005) Is there a relationship between childhood Helicobacter pylori and iron deficiency anemia? J Trop Pediatr 51, 166-169.

33. Ciacci C, Sabbatini F, Cavallaro R, Castiglione F, Di Bella S, Iovino P, Palumbo A, Tortora R, Amoruso D \& Mazzacca G (2004) Helicobacter pylori impairs iron absorption in infected individuals. Dig Liver Dis 36, 455-460.

34. Hacihanefioglu A, Edebali F, Celebi A, Karakaya T, Senturk O \& Hulagu S (2004) Improvement of complete blood count in patients with iron deficiency anemia and Helicobacter pylori after the eradication of Helicobacter pylori. Hepatogastroenterology 51, 313-315.

35. Annibale B, Marignani M, Monarca B, Antonelli G, Marcheggiano A, Martino G, Mandelli F, Caprilli R \& Delle Fave G (1999) Reversal of iron deficiency anemia after Helicobacter pylori eradication in patients with asymptomatic gastritis. Ann Intern Med 131, 668-672.

36. Choe YH, Kim SK, Son BK, Lee DH, Hong YC \& Pai SH (1999) Randomized placebo-controlled trial of Helicobacter pylori eradication for iron-deficiency anemia in preadolescent children and adolescents. Helicobacter 4, 135-139.

37. Mahalanabis D, Islam MA, Shaikh S, Chakrabarty M, Kurpad AV, Mukherjee S, Sen B, Khaled MA \& Vermund SH (2005) Haematological response to iron supplementation is reduced in children with asymptomatic Helicobacter pylori. Br J Nutr 94, 969-975.

38. Freire WB (1997) Strategies of the Pan American Health Organization/World Health Organization for the control of iron deficiency in Latin America. Nutr Rev 55, 183-188.

39. Goldman C, Barrado A, Janjetic M et al. (2006) Factors associated with $H$. pylori epidemiology in symptomatic children in Buenos Aires, Argentina. World J Gastroenterol 12, 5384-5388

40. Santos IS, Boccio J, Santos AS, Valle NC, Halal CS, Bachilli MC \& Lopes RD (2005) Prevalence of Helicobacter pylori and associated factors among adults in Southern Brazil: a population-based cross-sectional study. BMC Public Health 5, 118.

41. Paez Valery MC, Baron MA, Solano L, Nadaff G, Boccio J \& Barrado A (2006) Helicobacter pylori $\left({ }^{13} \mathrm{C}-\mathrm{UBT}\right)$, and its relationship with nutritional and socioeconomic factors in low income school children from Valencia, Venezuela. Arch Latinoam Nutr 56, 342-349.

42. Figueroa G, Acuna R, Troncoso M, Portell DP, Toledo MS \& Valenzuela J (1997) Helicobacter pylori in Chile. Clin Infect Dis 25, 983-989.

43. Glynn MK, Friedman CR, Gold BD, Khanna B, Hutwagner L, Iihoshi N, Revollo C \& Quick R (2002) Seroincidence of Helicobacter pylori in a cohort of rural Bolivian children: acquisition and analysis of possible risk factors. Clin Infect Dis 35, 1059-1065.

44. Torres J, Leal-Herrera Y, Perez-Perez G, Gomez A, Camorlinga-Ponce M, Cedillo-Rivera R, Tapia-Conyer R \& 
Muñoz O (1998) A community-based seroepidemiologic study of Helicobacter pylori in Mexico. J Infect Dis 178, 1089-1094.

45. Barrado A, Boccio J \& Valencia ME (2004) The usefulness of stable isotopes in nutrition and human health: the application of mass spectrometry and ${ }^{13} \mathrm{C}$-urea breath test to detect Helicobacter pylori. Arch Latinoam Nutr 54, Suppl., S27-S43.

46. World Health Organization (2001) Iron Deficiency Anaemia: Assessment, Prevention and Control. A Guide for Programme Managers. WHO/NHD/01.3. Geneva: WHO.

47. Matijasevich A, Victora CG, Barroa AJ, Santos IS, Marco PL, Albernaz EP \& Barros FC (2008) Widening ethnic disparities in infant mortality in southern Brazil: comparison of 3 birth cohorts. Am J Public Health 98, 692-698.

48. Olinto MT \& Olinto BA (2000) Race and inequality among women: an example in southern Brazil. Cad Saude Publica 16, 1137-1142.

49. Universidad Nacional de Luján (2007) Tabla de Composición Química de Alimentos. http://www.unlu.edu.ar/ $\sim$ argenfood/Tablas/Tabla.htm (accessed November 2007).

50. Food and Agriculture Organization of the United Nations (2007). The International Network of Food Data Systems. http://www.fao.org/infoods/index_en.stm (accessed November 2007).

51. US Department of Agriculture, Agricultural Research Service (2007) USDA National Nutrient Database for Standard Reference. Nutrient Data Laboratory Home Page. http://www.ars.usda.gov/nutrientdata (accessed November 2007).

52. Kuczmarski RJ, Ogden CL, Guo SS et al. (2000) CDC Growth Charts: United States. Advance Data from Vital and Health Statistics no. 314. Hyattsville, MD: National Center for Health Statistics.

53. Choi JW (2003) Does Helicobacter pylori relate to iron deficiency anaemia in prepubescent children under 12 years of age? Acta Paediatr 92, 970-972.

54. Pilotto A, Fabrello R, Franceschi M, Scagnelli M, Soffiati G, Di Mario F, Fortunato A \& Valerio G (1996) Helicobacter pylori in asymptomatic elderly subjects living at home or in a nursing home: effects on gastric function and nutritional status. Age Ageing 25, 245-249.

55. Digirolamo AM, Perry GS, Gold BD, Parkinson A, Provost EM, Parvanta I \& Grummer-Strawn LM (2007) Helicobacter pylori, anemia, and iron deficiency: relationships explored among Alaska native children. Pediatr Infect Dis J 26, 927-934.

56. Schubert ML (2007) Gastric secretion. Curr Opin Gastroenterol 23, 595-601.

57. Capurso G, Ricci R, Panzuto F, Baccini F, Passi S, Di Giulio E, Delle Fave G \& Annibale B (2003) Intragastric ascorbic but not uric acid is depleted in relation with the increased $\mathrm{pH}$ in patients with atrophic body gastritis and $H$. pylori gastritis. Helicobacter 8, 300-306.

58. Pellicano R \& Rizzetto M (2004) Is hepcidin the bridge linking Helicobacter pylori and anemia of chronic infection? A research proposal. Panminerva Med 46, $165-169$.
59. Choe Y, Oh Y, Lee N, Imoto I, Adachi Y, Toyoda N \& Gabazza EC (2003) Lactoferrin sequestration and its contribution to iron-deficiency anemia in Helicobacter pylori-infected gastric mucosa. J Gastroenterol Hepatol 18, 980-985.

60. Sarker SA, Davidsson L, Mahmud H, Walczyk T, Hurrell RF, Gyr N \& Fuchs GJ (2004) Helicobacter pylori, iron absorption, and gastric acid secretion in Bangladeshi children. Am J Clin Nutr 80, 149-153.

61. Bravo L, van Doorn L, Realpe L \& Correa P (2002) Virulence-associated genotypes of Helicobacter pylori: do they explain the African enigma? Am J Gastroenterol 97, 2839-2842.

62. Censini S, Lange C, Xiang Z, Crabtree JE, Ghiara P, Borodovsky M, Rappuoli R \& Covacci A (1996) cag, a pathogenicity island of Helicobacter pylori, encodes type I-specific and disease-associated virulence factors. Proc Natl Acad Sci USA 93, 14648-14653.

63. Cover T, Glupczynski Y, Lage A, Burette A, Tummuru MK, Perez-Perez GI \& Blaser MJ (1995) Serologic detection of with cagA + Helicobacter pylori strains. J Clin Microbiol 33, 1496-1500.

64. Garza-González E, Bosques-Padilla FJ, Tijerina-Menchaca R \& Perez-Perez GI (2004) Characterization of Helicobacter pylori isolates from the north-eastern region of Mexico. Clin Microbiol Infect 10, 41-45.

65. Yahav J, Fradkin A, Weisselber B, Diver-Haver A, Shmuely H \& Jonas A (2000) Relevance of CagA positivity to clinical course of Helicobacter pylori in children. J Clin Microbiol 38, 3534-3537.

66. Jimenez F, Demaria JL, Ahumada C, Nagel A, Baroni MR, Giugni MC \& Méndez E (2004) Seroprevalence of Helicobacter pylori, anti-CagA antibodies and its relationship with epidemiologic factors in Santa Fe. Acta Gastroenterol Latinoam 34, 16-20.

67. Noyan V, Apan TZ, Yucel A \& Sagsoz N (2004) Cytotoxin associated gene A-positive Helicobacter pylori strains in dyspeptic pregnant women. EurJ Obstet Gynecol Reprod Biol 116, 186-189.

68. Ladeira MS, Rodrigues MA, Salvadori DM, Neto PP, Achilles P, Lerco MM, Rodrigues PA, Gonçalves I Jr, Queiroz DM \& Freire-Maia DV (2004) Relationship between cagA, vacA and iceA genotypes of Helicobacter pylori and DNA damage in the gastric mucosa. Environ Mol Mutagen $\mathbf{4 4}$, 91-98.

69. Rugge M, Busatto G, Cassaro M, Shiao YH, Russo V, Leandro G, Avellini C, Fabiano A, Sidoni A \& Covacci A (1999) Patients younger than 40 years with gastric carcinoma, Helicobacter pylori genotype and associated gastritis phenotype. Cancer 85, 2506-2511.

70. Raghavan S \& Holmgren J (2005) CD4+CD25+ suppressor $\mathrm{T}$ cells regulate pathogen induced inflammation and disease. FEMS Immunol Med Microbiol 44, 121-127.

71. Gessner BD, Baggett HC, Muth PT, Dunaway E, Gold BD, Feng Z \& Parkinson AJ (2006) A controlled, householdrandomized, open-label trial of the effect that treatment of Helicobacter pylori has on iron deficiency in children in rural Alaska. J Infect Dis 193, 537-546. 